\title{
Antibacterial potential of Caesalpinia bonducella extracts and their isolated phytoconstituents: In vitro and in silico analysis
}

\author{
S R Santosh Kumar', Sudhesh L Shastri ${ }^{1}$, Venkatesh R², K Pradeepa ${ }^{3}$, V Krishna ${ }^{1 *}$ \\ 'Department of Biotechnology, Kuvempu University, Shankaraghatta, Shimoga, Karnataka, India, \\ ${ }^{2}$ Department of Biochemistry, Indian Institute of Science, Bengaluru, Karnataka, India \\ ${ }^{3}$ Department of P.G., Studies and Research in Biotechnology, Sahyadri Science College, Kuvempu University, Shimoga, Karnataka
}

\begin{tabular}{|c|c|}
\hline ARTICLE INFO & ABSTRACT \\
\hline $\begin{array}{l}\text { Article history: } \\
\text { Received on: July 30, } 2018 \\
\text { Accepted on: August 29, } 2018 \\
\text { Available online: April 05, } 2019\end{array}$ & \multirow{2}{*}{$\begin{array}{l}\text { The antimicrobial activity of Caesalpinia bonducella extracts such as CLC, CLE, CSC, and CSE and the } \\
\text { phytoconstituents such as } \beta \text {-Sitosterol (LC3) isolated from CLC and methyl (4E)-5-\{2-[(1E)-buta-1,3-dien-1-yl]- } \\
4,6 \text {-dihydroxyphenyl }\} \text { pent-4-enoate (SC2) isolated from CSC were evaluated on gram-positive and gram-negative } \\
\text { bacteria. The extracts and isolated compounds were found to have moderate-to-significant bacterial inhibition. The } \\
\text { significant activity was observed in the inhibition of Pseudomonas aeruginosa by CLC extract (16.10 } \pm 1.10 \mathrm{~mm}) \text {, } \\
\text { whereas the isolated phytocomponent SC2 showed the highest inhibition }(16.50 \pm 0.58 \mathrm{~mm}) \text {. Further, the isolated } \\
\text { compounds were subjected to molecular docking studies of the bacterial DNA Gyrase. The in silico study showed } \\
\text { the docking energy of }-6.4 \text { and three hydrogen bonding. This in vitro and in silico analysis of extracts and isolated } \\
\text { phytocomponents of } C \text {. bonducella helps to understand and evaluate the therapeutic efficacy to cure infectious } \\
\text { diseases and also supports the traditional medicinal claim as an antibiotic. }\end{array}$} \\
\hline $\begin{array}{l}\text { Key words: } \\
\text { Caesalpinia bonducella, } \\
\text { Antimicrobial activity, } \\
\text { Molecular docking study }\end{array}$ & \\
\hline
\end{tabular}

\section{INTRODUCTION}

One-third of global mortality is due to the infectious diseases because multidrug resistance pathogens are in escalation. Due to the restricted access to proper medicine and side effects caused by synthetic drugs, in many countries, people are still using herbal plants to treat the most prevalent infections (WHO, 2010) [1,2]. Hence, many studies have, therefore, been conducted to reveal the active phytoconstituents in such herbal plants. The present investigation is focusing on a threatened medicinally important legume species Caesalpinia bonducella (Roxb.). C. bonducella is classified under the family of Caesalpiniaceae. Commonly, it is called as Fever Nut and Bonduc Nut [3]. Leaves, seeds, stem, bark, nuts, and roots are used as herbal medicines. It is found in hotter parts of India, especially in Karnataka, and in the Western Ghats of India. In the conventional system of Indian medicine, Ayurveda, C. bonducella (Roxb.) is largely used for its antiperiodic, antipyretic, anti-inflammatory, anthelmintic, and antimalarial properties. It is also described to have antioxidant, antibacterial, antitumor, and antidiabetic activities [4].

The $C$. bonducella extracts and isolated phytoconstituents were screened for antibacterial activity against strains of the most common

\section{Corresponding Authors:}

Prof. V Krishna, Department of Biotechnology, Kuvempu University, Shankaraghatta, Shimoga, Karnataka, India. Phone: +91-9448681856. E-mail: krishnabotech2003@gmail.com pathogenic Gram-positive bacteria, namely Bacillus subtilis, and Gram-negative bacteria, namely Pseudomonas aeruginosa and Escherichia coli. The in silico analysis was done by docking the isolated phytoconstituents with bacterial DNA gyrase. DNA gyrase is an enzyme that influences all metabolic processes involving DNA by regulating negative supercoiling of bacterial DNA and is essential for replication. Inhibition of gyrase subunit affects breakage and rejoining of DNA and blocks relaxation of supercoiled DNA, thereby affecting metabolic pathways, transcription, and replication $[5,6]$. The in silico analysis was carried out in support to the in vitro antibacterial activity of extracts and isolated phytoconstituents of $C$. bonducella.

As to study the detailed antibacterial potential of extracts, phytoconstituents, and therapeutic efficacy to cure infectious diseases and also to authenticate the traditional medicinal claim of $C$. bonducella, this objective was taken and has been carried out accordingly. In the present investigation, effort has been made to authenticate the traditional value of $C$. bonducella against antimicrobial activity of extracts and phytoconstituent by in vitro and in silico.

\section{MATERIALS AND METHODS}

\subsection{Extraction and Isolation of Phytocomponent}

The leaves and stem bark of $C$. bonducella were collected from Shimoga, Karnataka, during October, and the plant material was authenticated by Prof. Y L Krishnamurthy, Department of Applied Botany, Kuvempu University (Voucher Specimen No: KUAB301). 
The leaves and stem bark were cleaned with deionized water and were shade dried, grounded porously using a mechanical blender, and passed through a 40 -mesh sieve. About $1 \mathrm{~kg}$ of powdered material was loaded into Soxhlet thimble and extracted with chloroform and ethanol for about $48 \mathrm{~h}$. The extracts were filtered (Whatman No.1 filter paper) and concentrated in vacuum under reduced pressure using rotary flash evaporator (Buchi, Flawil, Switzerland). The solvent was removed carefully at reduced pressure and dried in a desiccator. The dried leaf chloroform extract (CLC), leaf ethanol extract (CLE), stem bark chloroform extract (CSC), and stem bark ethanol extract (CSE) were subjected to preliminary phytochemical analysis. The leaves and stem bark chloroform extract were subjected to thin-layer chromatography (TLC) using the solvent system petroleum ether and chloroform. The pure constituents were eluted by column chromatography $(60 \mathrm{~cm} \times$ $4 \mathrm{~cm}, 60-120 \mathrm{mesh}, 200 \mathrm{~g}$ silica gel) by gradient elution method using petroleum ether/chloroform/hexane in combination, and the fractions were collected at the intervals of $5 \mathrm{~min}$. The purity of the isolated compounds confirmed by a single spot in TLC. These isolated pure compounds were characterized for structural prediction by nuclear magnetic resonance (HNMR), C13NMR, and LC-MASS, labeled as leaf chloroform (LC3) and stem bark chloroform (SC2), and stored for screening biological activity $[7,8]$.

\subsection{Microbial Strains}

Clinically isolated pathogenic Gram-positive bacteria, namely B. subtilis, and Gram-negative bacteria, namely P. aeruginosa and E. coli, were obtained from the National Chemical Laboratory and Institute of Medical Sciences, Shivamogga. All the bacterial microorganisms were maintained at $-30^{\circ} \mathrm{C}$ in brain heart infusion containing $17 \%(\mathrm{v} / \mathrm{v})$ glycerol. Before testing, the suspensions were transferred to $\mathrm{LB}$ broth and cultured overnight at $37^{\circ} \mathrm{C}$. Inoculum was prepared by adjusting the turbidity of the medium to match the 0.5 McFarland standards. Dilutions of this suspension in $0.1 \%$ peptone $(w / v)$ solution in sterile water were inoculated on LB agar, to check the viability of the preparations [7].

\subsection{Antimicrobial Activity}

Antimicrobial activity was tested by employing agar well diffusion method $[9,10]$ to assess the antimicrobial activity of the test samples CLC, CLE, CSC, CSE, LC3, and SC2. Sterilized LB agar (tryptone $10 \mathrm{~g} / 1$, yeast extract $5 \mathrm{~g} / 1$, sodium chloride $10 \mathrm{~g} / 1$, agar-agar $15 \mathrm{~g} / 1$, and $\mathrm{pH}$ 7.2) medium was poured into sterilized Petri dishes $(90-\mathrm{mm}$ diameter). LB broth containing $100 \mu \mathrm{L}$ of $24-\mathrm{h}$ incubated cultures of the respective strains was spread separately on the agar medium. Wells were created using a sterilized cork borer under aseptic conditions.

The chloroform and ethanol extracts at concentration $20 \mathrm{mg} / \mathrm{mL}$, $\beta$-Sitosterol and methyl (4E)-5-\{2-[(1E)-buta-1,3-dien-1-yl]-4,6dihydroxyphenyl $\}$ pent-4-enoate at concentration $5 \mathrm{mg} / \mathrm{mL}$, dissolved in dimethyl sulfoxide (DMSO), and the reference antibiotic ciprofloxacin (1 $\mathrm{mg} / \mathrm{mL}$, Cipla, Mumbai) were loaded in the corresponding wells. As a control, the wells were loaded with the same volume of sterile DMSO. Plates were then incubated at $37^{\circ} \mathrm{C}$ for $18 \mathrm{~h}$. After the incubation period, the zone of inhibition was calculated (in $\mathrm{mm}$ ), and data were statistically evaluated.

\subsection{Minimum Inhibitory Concentration (MIC) of Extract and Isolated Constituents}

MIC values were determined by broth dilution method. Serial dilutions (final volume of $1 \mathrm{~mL}$ ), chloroform and ethanol extract, and the constituent of C. bonducella ( 0.5 to $0.05 \mathrm{mg} / \mathrm{mL})$ were performed with $0.9 \%$ saline. Following this, $9 \mathrm{~mL}$ of nutrient broth was added. Broths were inoculated with $100 \mu \mathrm{L}$ of each bacterial suspension $(5 \times 104 \mathrm{CFU})$ and incubated for $24 \mathrm{~h}$ at $37^{\circ} \mathrm{C}$. Ciprofloxacin was used as the positive control and $0.9 \%$ saline as negative control. After $24 \mathrm{~h}$, bacterial growth was assayed by measuring absorbance at $625 \mathrm{~nm}$ [11].

\subsection{Statistical Analysis}

The analysis of variance (ANOVA) and significance were calculated using ezANOVA (version 0.98) software to determine the mean and standard error of zone of inhibition values between the extracts against bacterial culture [12].

\subsection{Molecular Docking Studies}

The structure of the target bacterial DNA gyrase was obtained from Protein Data Bank (PDB) (PDB ID; 3G75). Structures of phytoconstituents isolated, $\beta$-Sitosterol, and Methyl (4E)-5-\{2[(1E)-buta-1,3-dien-1-yl]-4,6-dihydroxyphenyl $\}$ pent-4-enoate were drawn and analyzed using ChemDraw Ultra 12.0. Three dimensional coordinates were obtained using PRODRG online server [13]. Active pockets for protein were obtained from CASTp server [14]. Intermediary steps such as energy minimization, protein, and ligands preparation and grid box creation were completed using Graphical User Interface program AutoDock Tools. AutoDock saved the prepared file in PDBQT format. AutoDock/Vina was employed for docking using protein and ligand information along with grid box properties in the configuration file. AutoDock/Vina employs an iterated local search global optimizer $[15,16]$. During the docking procedure, both the protein and ligands are considered as rigid. The results $<1.0 \AA$ in positional root-mean-square deviation were clustered together and represented by the result with the most favorable free energy of binding. The pose with the lowest energy of binding or binding affinity was extracted and aligned with receptor structure for further analysis $[7,17]$.

\section{RESULTS}

\subsection{Extraction and Isolation of Phytocomponent}

The careful interpretation and mechanistic investigations using infrared (IR), NMR, and mass spectral studies of isolated compound, $\beta$-sitosterol (LC3), isolated from the chloroform extract of stem bark of C. bonducella gave proof for the structure of isolated compounds [8]. Sitosterol is one of the several phytosterols with chemical structures similar to that of cholesterol. Sitosterols are white, waxy powders with a characteristic odor. They are hydrophobic and soluble in alcohol. Molecular formula is $\mathrm{C}_{29} \mathrm{H}_{48} \mathrm{O}$ and IUPAC Name 17-(5Ethyl-6methylheptan-2-yl)-10,13 dimethyl-2,3,4,7,8,9,11,12,14,15,16,17dodecahy-dro-1H cyclopenta [a] phenanthren-3-ol [Figure 1]. Methyl (4E)-5-\{2-[(1E)-buta-1,3-dien-1-yl]-4,6-dihydroxyphenyl $\}$ pent-4enoate (SC2) [8] compound isolated from the stem bark chloroform extract of $C$. bonducella. IR spectra showed a strong absorbance frequency at $3392 \mathrm{~cm}^{-1}$ observed for the $-\mathrm{OH}$, strong absorbance frequency at $2920 \mathrm{~cm}^{-1}$ groups observed for the alkyl (-CH) groups, and strong absorbance frequency at $1692 \mathrm{~cm}^{-1}$ observed for the ester (-COO) group. 1HNMR spectra showed the singlet and multiplet appearence at the region of 7.2-7.5 $\delta$ value which is confirmed the presence of three aromatic protons. The singlets appeared at the region of 5.8 and $6.5 \delta$ value are for two $-\mathrm{OH}$ groups. The peaks appeared at the region of 3.3-3.4 $\delta$ value are for $-\mathrm{CH}_{2}$ (methylene) protons. CNMR spectra showed the peak appeared at $176 \delta$ value which confirms the presence of aldehyde carbon. The peak appeared at $169 \delta$ 
value confirms the presence of $\mathrm{C}-\mathrm{OH}$ carbon. The peaks appeared at $118-146 \delta$ value confirm the presence of aromatic ring carbons. The peaks appeared at $71-100 \delta$ value confirm the presence of $-\mathrm{CH}=\mathrm{CH}$ carbons. The peak appeared at $57 \delta$ value confirms the presence of $-\mathrm{OCH}_{3}$ group. The peak appeared at $37-42 \delta$ value confirms the presence of aliphatic $(-\mathrm{CH})$ carbons. The analysis of spectral data revealed the structure of the phytocomponent isolated [Figure 2].

\subsection{Antimicrobial Activity}

The antibacterial activity of the leaves, stem bark extracts, and isolated phytoconstituents showed varying inhibition patterns with standard control. Among the leaves and stem bark extracts tested against bacterial strains (P. aeruginosa, E. coli, B. subtilis), the leaf chloroform extract showed a significant level of inhibition against all bacterial strains followed by stem bark chloroform extract. Leaf chloroform extract showed highest inhibition zone against P. aeruginosa $(16.10 \pm 1.10 \mathrm{~mm})$ and least against $E$. coli $(12.1 \pm$ $0.82 \mathrm{~mm}$ ). Stem bark ethanol extract and leaf ethanol extract showed comparatively least antibacterial activity against all bacterial strains. Among isolated phytoconstituents, SC2 has shown good inhibition $(16.50 \pm 0.58)$, whereas LC3 has shown less activity against bacterial pathogens comparatively. The results are represented graphically in Figure 3.

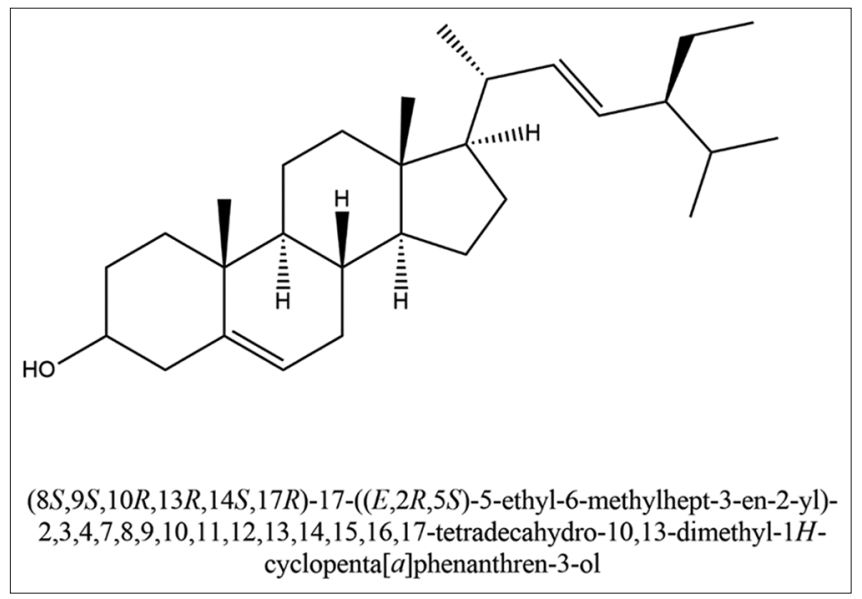

Figure 1: Structure of compound LC3: $\beta$-sitosterol

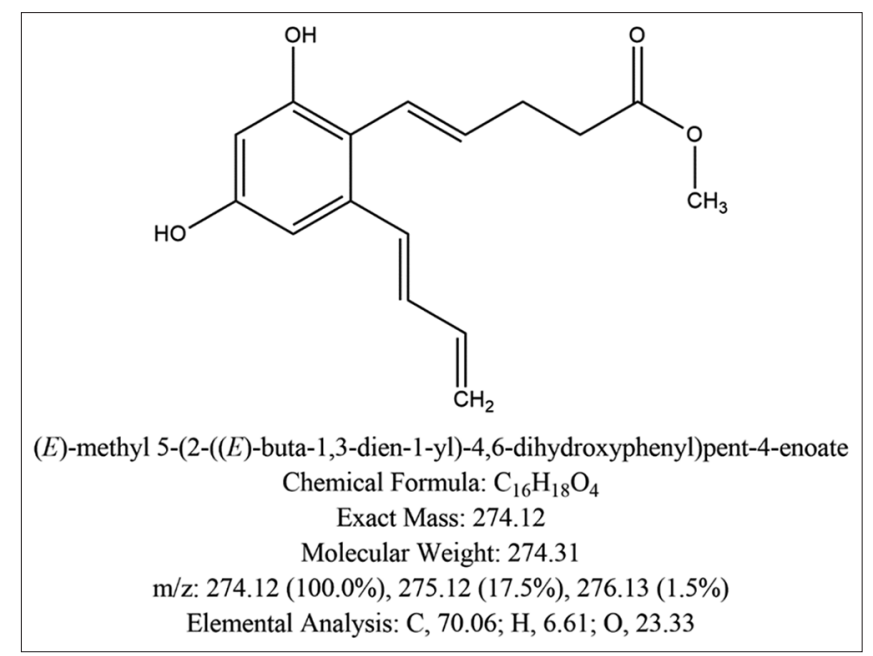

Figure 2: Structure of compound SC2: Methyl (4E)-5-\{2-[(1E)-buta-1,3-dien1-yl]-4,6-dihydroxyphenyl\} pent-4-enoate

\subsection{MIC of Extract and Isolated Constituents}

The extracts, CSC, showed inhibition at $2 \mathrm{mg} / \mathrm{mL}$ and $2 \mathrm{mg} / \mathrm{mL}$ for B. subtilis and P. aeruginosa, respectively. The CSC and CSE showed inhibition at $3 \mathrm{mg} / \mathrm{mL}$ for $E$. coli. Among phytocomponents, SC2 showed inhibition at $0.3 \mathrm{mg} / \mathrm{mL}, 0.2 \mathrm{mg} / \mathrm{mL}$, and $0.2 \mathrm{mg} / \mathrm{mL}$ for B. subtilis, $P$. aeruginosa, and E. coli, respectively. The MIC values of all extracts and the isolated constituents are represented in Figure 4.

\subsection{Molecular Docking Studies}

The two bioactive molecules were docked against bacterial DNA gyrase with a comparison to standard drug ciprofloxacin as shown in Figure 5a-c. The ligand molecule LC3 showed the highest binding affinity of -6.4 , one hydrogen bonding and good hydrophobic interaction against the amino acid molecules such as Thr171, His143,

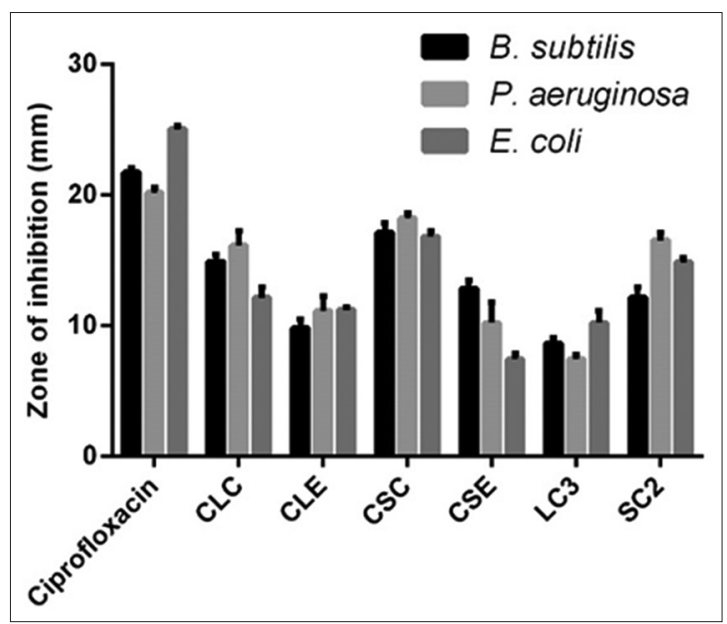

Figure 3: Antibacterial activity of leaf, stem bark extracts, and its isolated constituents. Ciprofloxacin; standard drug, CLC - leaf chloroform extract, CLE - leaf ethanol extract, CSC - stem bark chloroform extract, CSE - stem bark ethanol extract, LC3: $\beta$-sitosterol, SC2: Methyl (4E)-5-\{2-[(1E)-buta-1,3dien-1-yl]-4,6-dihydroxyphenyl $\}$ pent-4-enoate. Bars show means \pm standard error. The averages from three separate experiments are shown

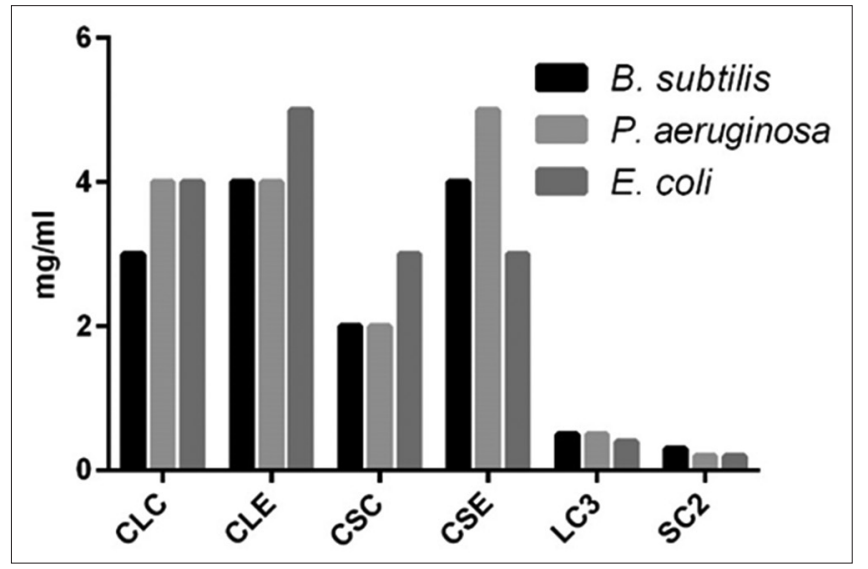

Figure 4: The minimum inhibitory concentration of leaf, stem bark extracts, and its isolated constituents. CLC - leaf chloroform extract, CLE - leaf ethanol extract, CSC - stem bark chloroform extract, CSE - stem bark ethanol extract, LC3: $\beta$-sitosterol, SC2: Methyl (4E)-5-\{2-[(1E)-buta-1,3-dien-1yl]-4,6-dihydroxyphenyl $\}$ pent-4-enoate. Bars show means of three separate experiments 

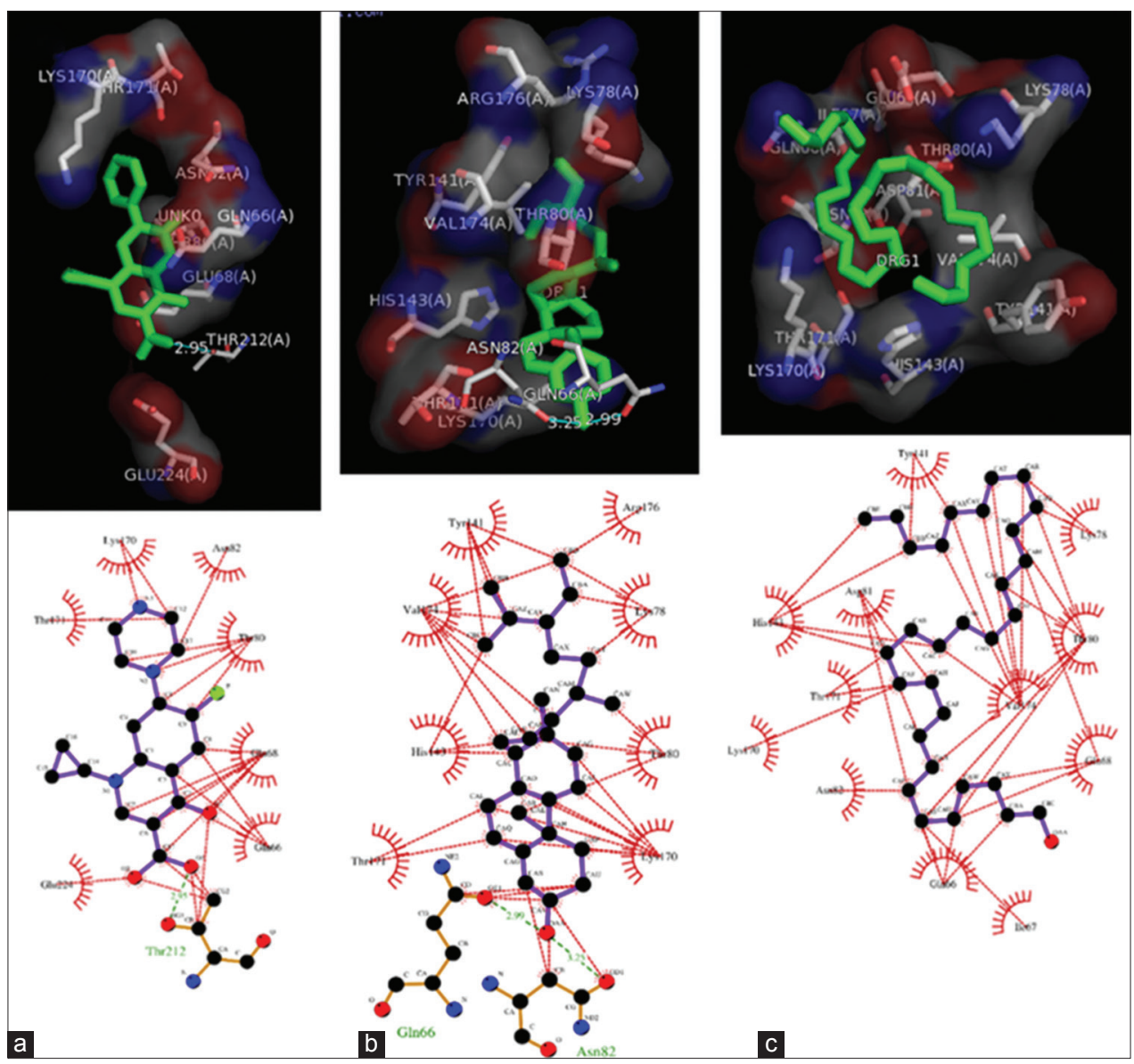

Figure 5: Molecular docking studies. (a) Two-dimensional (2D) ligplot analysis and docking results showing crystal structure bacterial DNA gyrase with the ligand ciprofloxacin (standard drug), (b) 2D Ligplot analysis and docking results showing crystal structure bacterial DNA gyrase with the ligand LC3, (c) 2D ligplot analysis and docking results showing crystal structure bacterial DNA gyrase with the ligand SC2

Val174, Tyr141, Arg176, Lys78, Thr80, and Lys170. It is predicted that the inhibition efficiency of the $C$. bonducella isolate is comparatively more than the standard drug [Table 1].

\section{DISCUSSION}

For a long period of time, plants have been a valuable resource for medical problems, including ailments caused by microbial infection. Numerous studies have been reported in different parts of the world to screen antimicrobial activity from plants products [18]. Due to the increasing prevalence of antibiotic-resistant pathogens in hospital and homes, the deliberate search is in progress for alternative treatments to combat the further spread of antibiotic-resistant pathogens [19]. Antibacterial drugs exert their action by interfering with either the structure or metabolic pathways of bacteria. In the present antibacterial study, we have selected ciprofloxacin as the standard drug to compare the therapeutic efficacy of test compounds. This is because of the specific characteristics of ciprofloxacin which contribute to a high therapeutic efficacy. Ciprofloxacin has a broad-spectrum bactericidal activity [20,21].

C. bonducella is used in traditional medicine to treat bacterial infections such as diarrhea and urinary tract infections. These traditional claims have been supported by the current bioassay results, and it has shown activity against human pathogenic bacteria $[3,22]$. Recorded results also supported the antibacterial activity of the $C$. bonducella against both Gram-positive bacteria, namely B. subtilis, and Gram-negative bacteria, namely $P$. aeruginosa and $E$. coli. The leaf chloroform extract and its isolated LC3 exhibit strong bactericidal activity against the selected bacterial strains.

Since the present study is purely a preliminary one, we cannot be as certain the reason for the efficient activity of the isolated compounds. The drug-pathogen interaction studies are still to be confirmed by profound investigation. However, our findings approve the bactericidal property of $C$. bonducella and provide a supportive scientific evidence for its medicinal use.

Several investigators have reported the bactericidal activity of some medicinal plants and their bioactive constituents on the same bacterial isolates for instance, Harish et al. reported the antibacterial activity of celapanin isolated from the leaves of Celastrus paniculatus; Naika et al. isolated that the taraxerol and $\beta$-sitosterol from petroleum ether extract of Naravelia zeylanica leaves; Sharath et al. screened the antibacterial activity of the crude methanolic extract and the isolated constituent, bacoside-A of Bacopa monnieri against 30 clinical strains isolated from different infectious sources which belong to Gram-negative P. aeruginosa, and Klebsiella pneumoniae, and Gram-positive $S$. aureus. Pradeepa et al. (2012) reported the antibacterial activity of ethanol extract of Litsea glutinosa stem bark. The earlier investigators, Simin et al. and Saeed and Sabir evaluated the antimicrobial activity of phytoconstituents of $C$. bonducella. The ethyl acetate and aqueous 
Table 1: Binding energy, H-Bonds, H-Bond length, H-Bond with, and Hydrophobic interactions of ligand with receptor

\begin{tabular}{|c|c|c|c|c|c|c|}
\hline Ligands & Target protein & $\begin{array}{c}\text { Affinity } \\
\text { (kcal/mol) }\end{array}$ & H-bonds & $\begin{array}{c}\text { H-bond } \\
\text { length }(\AA)\end{array}$ & $\begin{array}{l}\text { H-bond } \\
\text { with }\end{array}$ & $\begin{array}{l}\text { Hydrophobic } \\
\text { interactions }\end{array}$ \\
\hline LC3 & $\begin{array}{l}\text { Bacterial DNA } \\
\text { gyrase }\end{array}$ & 6.4 & 2 & $\begin{array}{l}2.99 \\
3.25\end{array}$ & $\begin{array}{l}\text { Gln66 } \\
\text { Asn } 82\end{array}$ & $\begin{array}{l}\text { Thr171, His143, } \\
\text { Val174, Tyr141, } \\
\text { Arg176, Lys78, Thr80, } \\
\text { Lys170 }\end{array}$ \\
\hline $\mathrm{SC} 2$ & & 5.1 & 1 & 3.05 & Gln66 & $\begin{array}{l}\text { Ile67, Thr80, Thr173, } \\
\text { Asn82, Asn81, Gly172, } \\
\text { Thr171, Lys170, } \\
\text { Glu68, Thr212 }\end{array}$ \\
\hline $\begin{array}{l}\text { Ciprofloxacin } \\
\text { (standard drug) }\end{array}$ & & 5.9 & 1 & 2.95 & Thr212 & $\begin{array}{l}\text { Thr171, Lys170, } \\
\text { Asn82, Thr80, Gln68, } \\
\text { Gln66, Glu224 }\end{array}$ \\
\hline
\end{tabular}

extracts of $C$. bonducella seeds exhibited high-to-moderate antifungal effect against the tested fungal species of Aspergillus niger, Candida albicans, Fusarium oxysporum, and Alternaria solani. Ali et al. reported the antibacterial, antidiarrheal, and cytotoxic activities of methanol extract and its fractions of $C$. bonducella leaves [23-30]. Since we tested the chloroform extract, ethanol extracts, and isolates of $C$. bonducella on clinically isolated pathogens, namely P. aeruginosa, E. coli, and B. subtilis, also the isolates were tested by in silico analysis as a supporting data for in vitro studies; in overall, the extract and isolates showed good inhibition of clinical pathogens; and by this, our work stood apart from previous investigations carried out on C. bonducella.

In the present study also, stem bark and leaf chloroform extract of $C$. bonducella showed a highly significant level of bacterial inhibition against $P$. aeruginosa, E. coli, and B. subtilis. The antibiotic effect of leaves chloroform extract was more significant than the stem bark chloroform extract. Leaf chloroform extract showed highest inhibition zone against $P$. aeruginosa and stem bark chloroform extract exhibits maximum inhibitory activity against $P$. aeruginosa. Molecular docking of two isolates with DNA gyrase in comparison with standard ciprofloxacin was done to support the in vitro antibacterial activity. The documented results reveal that the phytoconstituents LC3 and SC2 showed the higher binding affinity as well as two hydrogen bonding and good hydrophobic interaction with the receptor. Furthermore, by in silico analysis, it seems that LC3 and SC2 are promoting the remarkable antibacterial activity by the inhibition of bacterial DNA Gyrase.

\section{CONCLUSION}

The traditional claim indicated that the leaves and stem bark of C. bonducella are the potential sources of the drug. This investigation supported the traditional claim that stem bark chloroform extract and its isolated constituent exhibited high inhibition against bacterial pathogens. By in silico analysis, it seems that $\beta$ - Sitosterol and Methyl (4E)-5-\{2-[(1E)-buta-1,3-dien-1-yl]-4,6-dihydroxyphenyl $\}$ pent-4enoate are promoting the remarkable antibacterial activity through the inhibition of bacterial DNA gyrase.

\section{ACKNOWLEDGMENT}

The authors are thankful to DBT, New Delhi, India, for providing financial support through DBT-BUILDER program (Order No. BT/ PR9128/INF/22/190/2013, Dated: 30/06/2015) and the Kuvempu University administrative authority for offering the facility to carry out the work.

\section{REFERENCES}

1. Pan SY, Zhou SF, Gao SH, Yu ZL, Zhang SF, Tang MK, et al. New perspectives on how to discover drugs from herbal medicines: CAM's outstanding contribution to modern therapeutics. Evid Based Complement Alternat Med 2013;2013:627375.

2. Fair RJ, Tor Y. Antibiotics and bacterial resistance in the $21^{\text {st }}$ century. Perspect Medicin Chem 2014;6:25-64.

3. Khare CP. Indian Medicinal Plants: An Illustrated Dictionary. New York: Springer Science Business Media; 2007. p. 107-8.

4. Ali A, Rao NV, Shalam M, Gouda TS, Shantakumar SM. Anticonvulsive effect of seed extract of Caesalpinia bonducella (Roxb.). Iran J Pharmacol Ther 2009;8:51-5.

5. Cozzarelli NR. DNA gyrase and the supercoiling of DNA. Science 1980;207:953-60.

6. Chambers HF, Jawetz E. Sulfonamides, trimethoprim, and quinolones. In: Katzung BG, editor. Basic and Clinical Pharmacology. Norwalk, CT: Appleton-Lange; 1998. p. 765-7.

7. Shastri SL, Krishna V, Kumar SR, Kumar SR, Venkatesh R, Pradeepa K. Phytochemical analysis, antibacterial property and molecular docking studies of Mammea suriga kosterm. World J Pharm Sci 2016;4:331-40.

8. Kumar SR, Krishna V, Venkatesh R, Pradeepa K, Shastri SL. Evaluation of wound healing property of Caesalpinia bonducella leaves, stem bark extracts and their phytoconstituents. Int J Appl Adv Sci Res 2014;3080:36-49.

9. Kim H, Park SW, Park JM, Moon KH, Lee CK. Screening and isolation of antibiotic resistance inhibitors from the herb material resistant inhibition of 21 Korean plants. Nat Prod Sci 1995;1:50-4.

10. Nair R, Kalariya T, Chanda S. Antibacterial activity of some selected Indian medicinal flora. Turk J Biol 2005;29:41-7.

11. International Laboratory Standards. Need for International Laboratory Standards. Vol. 15. Wayne, PA: International Laboratory Standards; 2007. p. 1-5.

12. Azam SS, Abbasi SW. Molecular docking studies for the identification of novel melatoninergic inhibitors for acetylserotoninO-methyltransferase using different docking routines. Theor Biol Med Model 2013;10:63.

13. Schüttelkopf AW, van Aalten DM. PRODRG: A tool for highthroughput crystallography of protein-ligand complexes. Acta Crystallogr D Biol Crystallogr 2004;60:1355-63.

14. Tian W, Chen C, Lei X, Zhao J, Liang J. CASTp 3.0: Computed atlas of surface topography of proteins. Nucleic Acids Res 2018;46:W363-7.

15. Morris GM, Huey R, Lindstrom W, Sanner MF, Belew RK, Goodsell DS, et al. AutoDock4 and autoDockTools4: Automated docking with selective receptor flexibility. J Comput Chem 2009;30:2785-91.

16. Trott $\mathrm{O}$, Olson AJ. AutoDock vina: Improving the speed and accuracy of docking with a new scoring function, efficient optimization, and 
multithreading. J Comput Chem 2010;31:455-61.

17. Venkatesh R, Krishna V, Jayabaskaran C, Pradeepa K, Shastri SL, Lingaraju GM. Antimicrobial studies of stem bark extract and their phytoconstituent from Semecarpus anacardium L. Int J Fundam Appl Sci 2018;7:2-9.

18. Al Akeel R, Al-Sheikh Y, Mateen A, Syed R, Janardhan K, Gupta VC, et al. Evaluation of antibacterial activity of crude protein extracts from seeds of six different medical plants against standard bacterial strains. Saudi J Biol Sci 2014;21:147-51.

19. Ayukekbong JA, Ntemgwa M, Atabe AN. The threat of antimicrobial resistance in developing countries: Causes and control strategies. Antimicrob Resist Infect Control 2017;6:1-8.

20. Chouhan S, Sharma K, Guleria S. Antimicrobial activity of some essential oils-present status and future perspectives. Medicines 2017;4:58.

21. Osonwa UE, Ugochukwu JI, Ajaegbu EE, Chukwu KI, Azevedo RB, Esimone CO. Enhancement of antibacterial activity of ciprofloxacin hydrochloride by complexation with sodium cholate. Bull Fac Pharm Cairo Univ 2017;55:233-7.

22. Tambekar DH, Khante BS. Antibacterial properties of traditionally used medicinal plants for enteric infections by adivasi's (BHUMKA) in melghat forest (Amravati District). Int $\mathrm{J}$ Pharm Sci Res 2011;1:120-8.

23. Harish BG, Krishna V, Sharath R, Swamy HM, Naika HR, Mahadevan KM. Antibacterial activity of celapanin, a sesquiterpene isolated from the leaves of celastrus paniculatus wild. Int J Biomed Pharm Sci 2007;1:65-8.

24. Naika HR, Krishna V, Lingaraju K, Chandramohan V, Dammalli PN,
Suresh ND. Molecular docking, dynamics studies of bioactive compounds from Naravelia zeylanica (L.) DC. against GSK-3 beta protein. J Taibah Univ Sci 2014;9:1.

25. Rajashekharappa S, Krishna V, Sathyanarayana BN, Gowdar HB. Anti-bacterial activity of bacoside-a-an active constituent isolated of Bacopa monnieri (L.) Wettest. Pharmacologyonline 2008;2:517-28.

26. Pradeepa K, Krishna V, Venkatesh R, Kumar KG, Thirumalesh BV, Kumar KJ. Antibacterial screening of the stem bark and leaf extracts of Litsea glutinosa (Lour.) C.B. Rob-an ethnomedicinally important tree of the Western Ghats. Pharmacogn J 2011;3:72-6.

27. Simin K, Khaliq-uz-Zaman SM, Ahmed VU. Antimicrobial activity of seed extract and bondenolide from Caesalpinia bonduc (L.) Roxb. Phytother Res 2001;15:437-40.

28. Saeed MA, Sabir AW. Antibacterial activity of Caesalpinia bonducella seeds. Fitoterapia 2001;72:807-9.

29. Ali R, Billah M, Hassan M, Dewan SM. Enhydra fluctuans Lour a review. Res J Pharm Technol 2013;6:927-9.

30. Shukla S, Metha P, Metha A, Vyas SP, Bajpai VK. Preliminary phytochemical and antifungal screening of various organic extracts of Caesalpinia bonducella seeds. Rom Biotechnol Lett 2011;16:6384-9.

\section{How to cite this article:}

Kumar SRS, Shastri SL, Venkatesh, Pradeepa K, Krishna V. Antibacterial potential of Caesalpinia bonducella extracts and their isolated phytoconstituents: In vitro and in silico analysis. J App Biol Biotech. 2019;7(03):41-46. DOI: 10.7324/JABB.2019.70308 